\title{
Determination of Crop Water Requirement and Irrigation Water Requirement for Coffee Arabica (Coffea Arabica L.): Case Study of Somodo Watershed
}

\author{
Etefa Tilahun Ashine* \\ Ethiopian Institute of Agricultural Research \\ Jimma Agricultural Research Center
}

\begin{abstract}
*Corresponding Author: Etefa Tilahun Ashine, Ethiopian Institute of Agricultural Research, Jimma Agricultural Research Center
\end{abstract}

\begin{abstract}
Seasonal water deficit and climate change are among the major problems affecting the production and productivity of coffee arabica (coffee arabica L.). For its cultivation, farmers use irrigation but, they never realize how much water to apply. Therefore, the objective of this study was to determine the crop water requirement, irrigation water requirement and schedule for the cultivation of coffee Arabica in Somodo watershed. It was determined by using CROPWAT8.O by dividing the development stage of the crop in to four season; initial, development, mid and late season and carried out with inputs of climatic, crop and soil data. Soil samples were collected at five different depths to determine irrigation schedule. The result reveals that CWR of the crop was $217 \mathrm{~mm}$, 430mm, 497mm and 424mm; and IWR was 205mm, 334mm, 67mm and $87 \mathrm{~mm}$ depth of water per tree for the initial, development, mid and late season, respectively. Irrigation schedule starts on January first, $25^{\text {th }}$ day, $45^{\text {th }}$ day, $68^{\text {th }}$ day, $101^{\text {st }}$ day, and $305^{\text {th }}$ day with a gross quantity of $173.7 \mathrm{~mm}, 136.8 \mathrm{~mm}, 140.5 \mathrm{~mm}, 148.8 \mathrm{~mm}$, and $159.4 \mathrm{~mm}$ depth of water per tree, respectively. However, Investigation should continue from seedling stage to relate the yield and growth parameter of the crop.
\end{abstract}

Keywords: coffee arabica, Crop water requirement, Irrigation water requirement, Somodo watershed

\section{INTRODUCTION}

Coffee belongs to the genus Coffea, in the Rubiacea family. It is produced in most African countries and plays a central role in the national economies of Ethiopia (ICO, 2009). It contributes over $60 \%$ of the foreign exchange earnings and $30 \%$ of the government's direct revenue. Furthermore, the livelihood of $25 \%$ of the population depends on the coffee industry (Tesfaye and Ismail, 2008). However, the average national yield of the crop is very low primarily because of lack of improved varieties for different areas, diseases and pests, seasonal water deficits and climate change (Kirda $e t$ al., 2004; Belachew et al., 2015).

Most evidence shows that climate change has appeared in recent years and immediately change common perception of many people in few years and makes looking forward the serious topics of all stake holders. Since early 1900s, climate variation has been perceived and the causes usually anthropogenic and natural drivers of climate (Masters etal., 2009). The effect of climate variation on natural systems has begun as one of the most critical issues of human kind (Jaramillo et al., 2011). Many finding proof that weather alteration is hastening at ample quicker stride than earlier that lead to irreversible changes in major earth systems and ecosystems (ITC, 2010).

In order to alleviate the problem of the climate change using irrigation is an ultimate option which can improve the soil moisture and helps for the growth and development of the crop root and increase the production and productivity of crops. It can be used for both annual as well as perennial crops. Coffee is one of the perennial crop used as cash crop in Ethiopia that helps the government to get foreign income and economic income for farmers. Even though it has high economic income, its production is limited because of poor level of soil moisture, lack of fertilizer and poor agronomic management (Tesfaye et al., 2013).

The introduction of irrigation reduces the percentage of dried flowers (stars) from 57\% to less than $5 \%$, with some percentages practically negligible (Maestri, 1987 and Thomaziello, 1999) as cited by 
Naan DanJain 2009. When the productivity results of non-irrigated, irrigated and fertigated coffee were compared, there were increases of $66 \%$ and $123 \%$ in the irrigated and fertigated crops, respectively (http://www.naandanjain.com).

When the seasonal water requirement of coffee Arabica (coffee Arabica L.) is studied, a minimum of 1200 to $1600 \mathrm{~mm}$ per annum, without too long a hot dry season is necessary for good growth and sustainable production of the crop (Wringley, 1988). Even though the minimum annual CWR of coffee is stated between $1200-1600 \mathrm{~mm}$, the irrigation water quantity needed is not determined in the agro ecology of Somodo watershed. Supplemental irrigation is required as the annual rainfall is less than the seasonal coffee crop water requirement and its distribution is usually erratic (Tesfaye et al., 2008).

In Somodo watershed there was a five hectar of coffee Arabica cultivated by using irrigation. For the cultivation of coffee Arabica (coffee Arabica L.) in the watershed during the dry period, farmers use irrigation by applying water to make the irrigation fields' soil feel muddy, blacken-up the soil or continue irrigating until the water reaches the end of every furrow. However, quite often they never realize just how much water they have applied. They may apply too little or too much water to the field. When they do not take their systems efficiency into account, they may apply too little or too much water. Too little water causes unnecessary water stress and can result in yield reductions. Too much water can cause water logging, leaching, and may also result in loss of yield. Hence, there is an urgent need to identify and adopt effective irrigation water management by determining Crop Water Requirement, and Irrigation water requirement of coffee Arabica (coffee arabica L.). Therefore, the objective of this study was to determine the quantity of crop water requirement, irrigation water requirement and irrigation schedule for the cultivation of coffee arabica (coffee arabica L.) in Somodo watershed.

\section{MATERiAls AND MethodS}

\subsection{Description of the Study Area}

\subsubsection{Location of the Study Area}

The study was conducted in Somodo watershed which is one of the watersheds located in Didessa sub-basin. It is a coffee producing areas in Manna district of Jimma Zone, located at approximately $361 \mathrm{~km}$ South-West of Addis Ababa and $12 \mathrm{~km}$ west of Jimma town. Geographically the study area extends from $7^{0} 46^{\prime} 00^{\prime \prime}-7^{0} 54^{\prime} 30^{\prime \prime} \mathrm{N}$ latitude and $36^{\circ} 46^{\prime} 30^{\prime \prime}-36^{0} 56^{\prime} 30^{\prime \prime} \mathrm{E}$ longitude. The total area of the watershed covers about 19860ha and the altitude ranges between 1647-2419 meter minimum and maximum elevation above sea level, respectively. It has a good agro ecologic zone which is suitable for many crop production including improved crop varieties, fruit crops, and cereal crops.

From the long term meteorological data, the minimum and maximum temperature of the watershed ranges between $13^{\circ} \mathrm{C}$ and $25^{\circ} \mathrm{C}$, respectively. The average annual rainfall is $1500 \mathrm{~mm}$ distributed unevenly throughout the year. The average relative humidity, solar radiation and wind speed of the watershed is $72 \%, 2.5 \mathrm{~m} / \mathrm{s}$ and $6.7 \mathrm{hr}$, respectively.

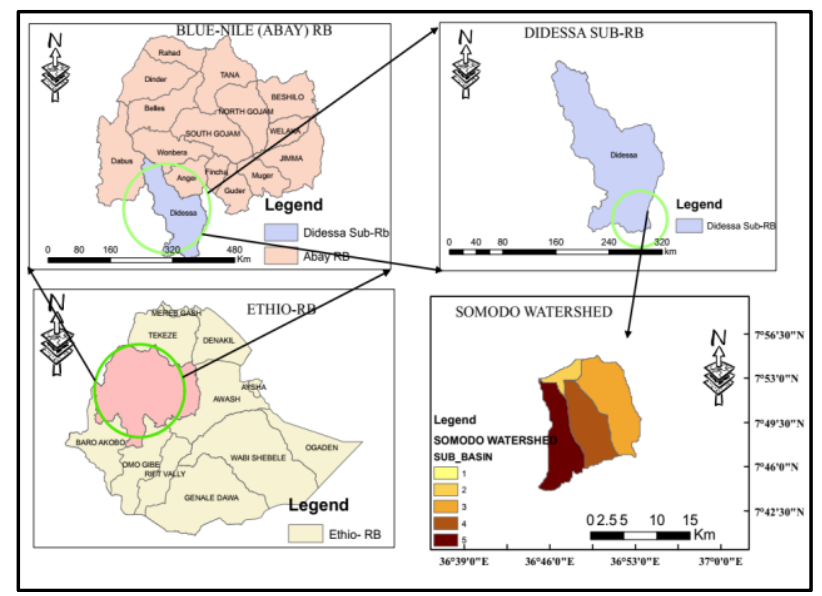

Figure1. Geographical location of the study area 


\subsection{Materials used for the study}

\subsubsection{Auger}

Auger was used to collect the soil sample. It is a material which was used to hoe the soil and collect the soil sample for further analysis in the laboratory to study the soil properties which were used as an input data for CROPWAT8.0 model.

\subsubsection{Global positioning system (GPS)}

GPS was used to collect the geographic information of the study area.

\subsubsection{Xlstat 2017}

The meteorological data mainly used as an input in this study were rainfall, minimum and maximum temperature, wind speed, solar radiation and relative humidity taken from the Ethiopian National Meteorological Agency (ENMA). But the data collected have a missing value. In order to fill the missing data, the trial version of xlstat2017 software was used.

\subsubsection{Geographical information system software (GIS)}

ARCGIS version 10.4.1 was used for locating the study area and for delineating the watershed.

\subsubsection{CROPWAT 8.0 model}

It was used to calculate the Crop Water Requirement, Irrigation Water Requirement and irrigation schedule for coffee Arabica. The input data were prepared using Microsoft excel.

\subsection{Methodology}

\subsubsection{Determination of crop water requirement}

The crop water requirement was calculated using ETo, $\mathrm{kc}$ and $\mathrm{P}_{\text {eff }}$ by the following equation.

$\mathrm{ETc}=\mathrm{Kc} \times \mathrm{ETo}$

IWR $=\mathrm{ETc}-\mathrm{P}_{\mathrm{eff}}$

Where: ETC- Crop evapotranspiration ( $\mathrm{mm} /$ period),

$P_{\text {eff }}$ - is effective rainfall $(\mathrm{mm})$,

IWR- is irrigation water requirement in ( $\mathrm{mm} /$ period),

Kc- is crop coefficient,

ETo- reference evapotranspiration ( $\mathrm{mm} / \mathrm{day})$.

ETo was calculated by FAO Penman-Monteith method using meteorological data (FAO, 1998). Crop coefficient $(\mathrm{Kc})$, crop growth stages, rooting depths, critical depletion fraction, yield responses factor, maximum crop height and length of growth stage were fixed according to local conditions of study area and using literature (FAO, 1998; Doorenbos and Pruitt, 1977; Allen et al., 1998). Effective rainfalls used for CWR was calculated procedurally using a 20 years' rain fall data by empirical formula in mm depth (Appendix table 1-3). The Penman-Monteith form of the combination equation is given by;

$$
E T_{o}=\frac{0.408 \Delta(R n-G)+\gamma \frac{900}{T+273} u 2\left(e_{s}-e a\right)}{\Delta+\gamma(1+0.34 u 2)}
$$

Where; ETo- reference evapotranspiration $\left(\mathrm{mm} \mathrm{day}^{-1}\right), \mathrm{Rn}$ - net radiation at the crop surface in $\left(\mathrm{MJ} \mathrm{m}^{-2}\right.$ day $\left.^{-1}\right), \mathrm{G}$-soil heat flux density $\left(\mathrm{MJ} \mathrm{m}^{-2}\right.$ day $\left.^{-1}\right), \mathrm{T}$-mean daily air temperature at $2 \mathrm{~m}$ height $\left({ }^{\circ} \mathrm{C}\right), \mathrm{u}_{2^{-}}$ wind speed at $2 \mathrm{~m}$ height $\left(\mathrm{m} \mathrm{s}^{-1}\right)$, es- saturation vapor pressure $(\mathrm{kPa})$, ea-actual vapor pressure $(\mathrm{kPa})$, (es-ea) - saturation vapor pressure deficit in $(\mathrm{kPa}), \Delta$-slope vapor pressure curve $\left(\mathrm{kPa}{ }^{\circ} \mathrm{C}^{-1}\right), \gamma$ psychometric constant $\left(\mathrm{kPa}^{\circ} \mathrm{C}^{-1}\right)$.

\subsubsection{Determination of Irrigation water requirement of coffee Arabica}

The CWR and irrigation requirement for coffee (Coffea arabica L.) was determined by the vegetative development characteristics, soil moisture depletion fraction of 0.45 and application efficiency of $70 \%$. 
Determination of Crop Water Requirement and Irrigation Water Requirement for Coffee Arabica (Coffea Arabica L.): Case Study of Somodo Watershed

It was determined by using the CROPWAT 8.0 model. The Crop Water Requirement and Irrigation Water Requirement were carried out with inputs of climatic, crop and soil data. Essential information used includes crop type and crop variety, crop coefficient $(\mathrm{Kc})$, rooting depth, allowable depletion levels, critical depletion fraction (p) and length of growth stages. Depth of Irrigation water requirement was calculated by deducting the effective rain fall in $\mathrm{mm}$ from the crop water requirement.

To determine irrigation schedule, representative soil samples were selected and collected from the watershed at five different depths; $0-30 \mathrm{~cm}, 30-60 \mathrm{~cm}, 60-90 \mathrm{~cm}, 90-120 \mathrm{~cm}$ and $120-150 \mathrm{~cm}$. The soil's fresh weights were measured using sensitive balance at each depth. After measuring the fresh weight, the soil was dried in the oven for 24 hours at $105^{\circ} \mathrm{C}$ and then its dry weight was measured. Finally, its permanent wilting point (PWP) and field capacity (FC) was determined using the following formula.

$\Theta_{\mathrm{m}}=\frac{(\mathrm{Ww}-\mathrm{Wd})}{\mathrm{Wd}}$

Where: $\Theta_{\mathrm{m}}$ is mass of soil moisture content at FC or PWP (\%),

$\mathrm{W}_{\mathrm{d}^{-}}$is weight of oven dried soil $(\mathrm{gm})$, and

$\mathrm{W}_{\mathrm{w}}$ - is weight of wet soil (gm).

\section{RESULT AND DISCUSSION}

\subsection{Reference Evapotranspiration $\left(\mathbf{E T}_{\mathbf{0}}\right)$}

The annual ETo varies between 4.8 and $3.39 \mathrm{mmday}^{-1}$, it was maximum in March and minimum in July, respectively and the average was 4.27 mmday $^{-1}$. For June, September, August and July (the summer season) it was below $4.0 \mathrm{~mm} /$ day but for the rest of the months it was above 4.0 mmday $^{-1}$. The variation may be mainly because of warm air and low humidity. During dry season, high amount of energy was available since temperature is high. ETo values during summer season (July to September) were very low and the summer season is a main rainy season in Somodo watershed. This low ETo value during rainy season may be due to low air temperature and high humidity as the result of continuous rain fall.

\subsection{Analysis of soil data}

Crop performance and efficient use of the available water can be optimized by determining the water holding capacity of the soil, the water requirements and response of each crop grown, using an effective soil moisture monitoring system and irrigation scheduling. Physical soil analysis collected from the watershed showed that the texture of the soil was clay loam and average moisture content on volume base at Field Capacity (FC) and Permanent Wilting Point (PWP) were 35.04\% and 25.41\%, respectively. Volumetric Total Available Water (TAW) was $167.62 \mathrm{~mm} / \mathrm{m}$ with bulk density of $1.74 \mathrm{gcm}^{-3}$ (table 1).

Table1. Result Soil data collected from the field

\begin{tabular}{|c|c|c|c|c|}
\hline $\begin{array}{c}\text { Soil depth } \\
(\mathrm{cm})\end{array}$ & $\begin{array}{c}\text { Bulk density } \\
\left(\mathrm{gcm}^{-3}\right)\end{array}$ & $\begin{array}{c}\text { Field capacity (vol } \\
\%)\end{array}$ & $\begin{array}{c}\text { Permanent wilting point } \\
(\text { vol \%) }\end{array}$ & $\begin{array}{c}\text { Total available } \\
\text { water }(\mathrm{mm} / \mathrm{m})\end{array}$ \\
\hline Soil texture & clay loam & clay loam & clay loam & 126.16 \\
\hline $0-30$ & 1.66 & 34.80 & 27.20 & 144.25 \\
\hline $30-60$ & 1.74 & 35.40 & 27.11 & 206.46 \\
\hline $60-90$ & 1.80 & 36.70 & 23.23 & 181.10 \\
\hline $90-120$ & 1.76 & 34.10 & 23.70 & 182.70 \\
\hline $120-150$ & 1.74 & 34.20 & 25.41 & 167.62 \\
\hline Average & 1.74 & 35.04 & & clay \\
\hline
\end{tabular}

\subsection{Effective rainfall}

From the total annual rain fall the effective precipitation was $571.88 \mathrm{~mm}$. Even though this quantity is high, the maximum effective rainfall occurs during high rainfall time (summer season) from May up to September, with $85.4 \mathrm{~mm}, 96.32 \mathrm{~mm}, 95.76 \mathrm{~mm}, 102.96 \mathrm{~mm}$, and $94.48 \mathrm{~mm}$, respectively (Appendix table 3). 


\subsection{CWR and IWR for coffee (Coffea arabica L.) crop}

The vegetative development stage of the crop was divided in to four season; initial, development, mid-season and late season. The initial stage of the crop includes time for buildup and initiation of flower buds, the development season includes time for flower bud formation and flowering, the midseason includes time for fruit development and maturity and the late season was the time for harvesting the coffee bean. The duration it takes from initiation of flower buds up to harvesting was a total of 305 days with a length of 50,65,100 and 90 days for initial, development, mid-season and late season, respectively in the agro-ecology of the study area.

Accordingly, the CWR of coffee arabica (Coffea arabica L.) in Somodo watershed was $217 \mathrm{~mm}$, $430 \mathrm{~mm}, 497 \mathrm{~mm}$ and $424 \mathrm{~mm}$ depth of water per tree for the initial, development, mid-season and late season, respectively. The IWR after deduction of effective rain fall was $205 \mathrm{~mm}, 334 \mathrm{~mm}, 67 \mathrm{~mm}$ and $87 \mathrm{~mm}$ depth of water per tree for the initial, development, mid-season and late season, respectively. Therefore, a total quantity of $1568 \mathrm{~mm}$ depth of water per tree was required for the crop and $693 \mathrm{~mm}$ depth of water should be fulfilled by irrigation for the cultivation of coffee (Coffea arabica L.) in Somodo watershed.

But, from the recommended agronomy practice, coffee is planted at a spacing of $2 \mathrm{mx} 2 \mathrm{~m}$ (Mekonen et al., 2018) and a total of $4 \mathrm{~m}^{2}$ areas were occupied for planting one coffee tree; hence the total volume of water required per tree was $6.27 \mathrm{~m}^{3}$ throughout the crop period. Therefore, the CWR of coffee (Coffea arabica L.) in Somodo watershed for one hectare of land was $15680 \mathrm{~m}^{3}$ of water throughout the crop period. The total volume of irrigation water required per tree was $2.772 \mathrm{~m}^{3}$. From the agronomy practice for cultivation of coffee crop at a spacing of $2 \mathrm{~m} \times 2 \mathrm{~m}$, a total volume of irrigation water required per hectare of land was $6930 \mathrm{~m}^{3}$ throughout the vegetative development and harvesting time. Therefore, irrigation water requirement of coffee crop for an area of five hectares was $34650 \mathrm{~m}^{3}$.

According to the CROPWAT8.0 model for a total of 305 days (from vegetative development up to harvesting) the irrigation should be given on January first day, $25^{\text {th }}$ day, $45^{\text {th }}$ day, $68{ }^{\text {th }}$ day, $101{ }^{\text {st }}$ day, and $305^{\text {th }}$ day with a gross irrigation water amount of $173.7 \mathrm{~mm}, 136.8 \mathrm{~mm}, 140.5 \mathrm{~mm}, 148.8 \mathrm{~mm}$, and $159.4 \mathrm{~mm}$ depth per tree, respectively.

In general, the CWR was lowest during the initial stage and highest during mid-season stage. However, it is relatively moderate during mid-season stage. In the agro-ecology of Somodo watershed irrigation water requirement is maximum during the development stage and it does not require irrigation during the summer season (June to September) this is because during summer rainy season there was high amount of effective rainfall and it is sufficient for the crop.

\section{CONCLUSION AND RECOMMENDATION}

As coffee is a perennial crop, it requires many years' data to determine a specific problem on crop water requirement and irrigation water requirement of the crop. Additionally, there are urgent problems that cause the reduction of its production and productivity, one of them is water deficit because of non-uniform distribution of rainfall and hence irrigation can be taken as a solution. Therefore, this study can respond a basic question on the irrigation water requirement (how much water to apply) and irrigation schedule (when to apply) for the cultivation of coffee arabica (coffea arabica L.) in Somodo agro-ecology.

Therefore, Irrigation water requirement of coffee arabica (coffee arabica L.) for the cultivation of five hectar of land was $34650 \mathrm{~m}^{3}$. It is possible to use $6930 \mathrm{~m}^{3}$ of water for one hectare of land in Somodo watershed for cultivation of coffee Arabica.

\section{RECOMMENDATION}

$>$ The crop water requirement and irrigation requirement for coffee was addressed by simply applying the CROPWAT 8.0 model by considering the vegetative characteristics. Therefore, it is highly recommended to do a further experimental research to determine the crop water requirement and irrigation schedule in the agro-ecology and cropping calendar from seedling up to the fly crop stage to relate to yield and yield components. 
Determination of Crop Water Requirement and Irrigation Water Requirement for Coffee Arabica (Coffea Arabica L.): Case Study of Somodo Watershed

Evapotranspiration mapping should be necessary for the effective management of irrigation for the cultivation of other crops in the watershed.

\section{ACKNOWLEDGEMENT}

The author would like to thank Tofik Abajihad, Natural Resources and Agricultural development worker of Jimma Zone Mana Woreda for providing me the necessary data and field visit of the agricultural site.

\section{REFERENCES}

[1] Allen, R., L.S. Pereira, D. Raes, and M. Smith (1998). Crop evapotranspiration Guidelines for computing crop water requirements. FAO Irrigation and Drainage Paper No 56. Rome, Italy.

[2] Doorenbos, J. and W.O. Pruitt (1977). Guidelines for predicting crop water requirements. Irrigation and Drainage Paper 24 (revised) Food and Agricultural Organization of the United Nations, Rome.

[3] FAO (Food and Agriculture Organization) (1998). Crop evapotranspiration: Guidelines for computing crop water requirements. By Richard Allen, Luis Pereira, Dirk Raes and Martin Smith. FAO Irrigation and Drainage Paper 56. Rome, Italy.

[4] http://www.naandanjain.com: accessed April 20, 2019.

[5] International Coffee Organization (ICO) (2009). ICO trade statistics, Exports by exporting countries to all destinations (www.ico.org/trade_statistics.asp).

[6] ITC (International Trade Centre) (2010). Climate Change and the Coffee Industry, Kasterine A., Scholer M, Hilten HJ (ed.), Geneva, Netherland.

[7] Jaramillo J, Muchugu E, Vega FE, Davis A, Borgemeister C (2011). The Influence and Implications of Climate Change on Coffee Berry Borer (Hypothenemus hampei) and Coffee Production in East Africa. PLoS ONE 6 (9): e24528. doi: 10.1371/journal.pone.0024528.

[8] Kifle Belachew, Demelash Teferi, and LegesseHagos (2015). Coffee Thread Blight (Corticium koleroga): A Coming Threat for Ethiopian Coffee Production. Plant Pathology and Microbiology 6: 1-6.

[9] Kirda, C., M.Cetin, Y. Dasgan, S. Topcu, H. Kaman, B. Ekici, M.R. Derici and A.I. Ozguven (2004). Yield response of greenhouse grown coffee to partial root drying and conventional deficit irrigation. Agric Water Manage 69:191-201.

[10] Masters G,Baker P, Flood J (2009). Climate Change and Agricultural Commodities. CABI Position Paper.

[11] Mekonnen, B., Temeteme, S., Getachew, E., Kifelew, H., \& Shimber, T (2018). Determination of Appropriate Planting Space and Vertical Numbers for Hybrid Arabica Coffee at Yeki District, Southwestern Ethiopia. J Hortic, 5(240), 2376-0354.

[12] Tesfaye Shimber G and M.R. Ismail (2008). The potential of deficit irrigation for coffee (Coffea arabica L.) production in Ethiopia. Addis Ababa, Ethiopia. Pp. 158 -162.

[13] Tesfaye Shimbir Gesesse, M.R. Ismail, H. Kausar, M. Marziah and M.F. Ramlan (2013). Plant water relations, crop yield and quality of Arabica coffee as affected by Supplemental deficit Irrigation. International Journal of Agriculture and Biology 15(4): 665-672.

[14] Tesfaye Shimbir, I.M. Razi and M. Maziah (2008). Effects of deficit irrigation and partial root zone drying on growth, dry matter partitioning and water use efficiency in young coffee plants. Journal of Food, Agriculture and Environment 6: 312-317.

[15] Wrigley G. (1988). Coffee Tropical Agriculture Series. Long man Scientific \& Technical, Singapore.

\section{APPENDIX}

\section{Procedures to determine the effective rainfall}

Appendix table1. Precipitation data of Jimma metrological station ( $\mathrm{mm}$ )

\begin{tabular}{|c|c|c|c|c|c|c|c|c|c|c|c|c|}
\hline Year & Jan & Feb & Mar & Apr & May & Jun & Jul & Aug & Sep & Oct & Nov & Dec \\
\hline 1997 & 66 & 0 & 68.7 & 178 & 274.6 & 236.9 & 122.4 & 256 & 148.1 & 336.7 & 243.2 & 36.1 \\
\hline 1998 & 102.5 & 22.4 & 96.5 & 93.2 & 183.6 & 222.6 & 248.4 & 306.7 & 199.9 & 200.7 & 46.5 & 1.4 \\
\hline 1999 & 29.8 & 0.7 & 82.4 & 71.8 & 213.7 & 175 & 136.1 & 102.3 & 130.9 & 197.8 & 1.3 & 2 \\
\hline 2000 & 0 & 1 & 39.3 & 194.7 & 237.7 & 153.7 & 265.9 & 158.7 & 255.2 & 244 & 46.8 & 24.9 \\
\hline 2001 & 16.2 & 12.9 & 85.9 & 116.8 & 341.2 & 299.4 & 312.3 & 160.8 & 183.4 & 162.9 & 75.8 & 3.8 \\
\hline 2002 & 68.9 & 5 & 91.2 & 89.7 & 137.3 & 241.6 & 149.7 & 234.9 & 165.3 & 79.6 & 8.1 & 138.4 \\
\hline 2003 & 28.7 & 61.3 & 86.9 & 111.3 & 12.2 & 272.2 & 186.7 & 150.9 & 238.9 & 91.7 & 29.9 & 14.6 \\
\hline 2004 & 51 & 28.4 & 46.1 & 130.9 & 161.9 & 128.4 & 216.3 & 219.4 & 201 & 133.2 & 67.3 & 84.2 \\
\hline
\end{tabular}

International Journal of Research Studies in Agricultural Sciences (IJRSAS) 
Determination of Crop Water Requirement and Irrigation Water Requirement for Coffee Arabica (Coffea Arabica L.): Case Study of Somodo Watershed

\begin{tabular}{|c|c|c|c|c|c|c|c|c|c|c|c|c|}
\hline 2005 & 44.5 & 0.5 & 193.8 & 141.4 & 173.8 & 177.2 & 273.5 & 227.8 & 229.1 & 68.3 & 29.7 & 0 \\
\hline 2006 & 15.8 & 77.1 & 181.8 & 110.3 & 211.5 & 207.4 & 327.2 & 240.2 & 169.9 & 91.1 & 127.6 & 100.2 \\
\hline 2007 & 37.5 & 51 & 104.1 & 121.6 & 196.1 & 142.6 & 247.4 & 177 & 256.2 & 50.8 & 5.9 & 0 \\
\hline 2008 & 34 & 12.3 & 39.4 & 112.7 & 249 & 238.2 & 209.8 & 236.8 & 133.4 & 186.1 & 92.9 & 6.3 \\
\hline 2009 & 63 & 29.5 & 79.8 & 103.1 & 243.6 & 160.3 & 149.6 & 304.7 & 209.4 & 92.2 & 78.4 & 67.7 \\
\hline 2010 & 27.3 & 88.4 & 67.4 & 101.4 & 192.9 & 394.7 & 181.3 & 203.5 & 186.5 & 37 & 96.2 & 10.5 \\
\hline 2011 & 24.1 & 7.5 & 39.3 & 151.2 & 192.9 & 311.2 & 189.9 & 192.1 & 269.5 & 10.3 & 104.9 & 26 \\
\hline 2012 & 2.1 & 1.8 & 55.8 & 154.5 & 118.7 & 335 & 223.9 & 132.7 & 250.5 & 32.8 & 77.4 & 57.7 \\
\hline 2013 & 34.9 & 31.3 & 109.4 & 95.8 & 306 & 193.3 & 151.5 & 255.2 & 183.3 & 167.8 & 114.7 & 1 \\
\hline 2014 & 17.8 & 16.8 & 115.3 & 0 & 0 & 117.4 & 271.3 & 265.6 & 142.3 & 155.5 & 134.9 & 25.9 \\
\hline 2015 & 6.1 & 16.9 & 77.5 & 176.3 & 212.5 & 308.6 & 256.9 & 243.2 & 249.9 & 143.1 & 155.2 & 88.8 \\
\hline 2016 & 39.4 & 70.7 & 81.4 & 238.3 & 286.8 & 150.4 & 240.2 & 344.3 & 174 & 171.9 & 54.5 & 17.4 \\
\hline
\end{tabular}

(Source: ENMA; 1997-2016)

Appendix table2. Rank of precipitation from the highest to the lowest

\begin{tabular}{|c|c|c|c|c|c|c|c|c|c|c|c|c|}
\hline Rank & Jan & Feb & Mar & Apr & May & Jun & Jul & Aug & Sep & Oct & Nov & Dec \\
\hline 1 & 102.5 & 88.4 & 193.8 & 238.3 & 341.2 & 394.7 & 327.2 & 344.3 & 269.5 & 336.7 & 243.2 & 138.4 \\
\hline 2 & 68.9 & 77.1 & 181.8 & 194.7 & 306 & 335 & 312.3 & 306.7 & 256.2 & 244 & 155.2 & 100.2 \\
\hline 3 & 66 & 70.7 & 115.3 & 178 & 286.8 & 311.2 & 273.5 & 304.7 & 255.2 & 200.7 & 141.4 & 88.8 \\
\hline 4 & 63 & 61.3 & 109.4 & 176.3 & 274.6 & 308.6 & 271.3 & 265.6 & 250.5 & 197.8 & 127.6 & 84.2 \\
\hline 5 & 51 & 51 & 104.1 & 154.5 & 249 & 299.4 & 265.9 & 256 & 249.9 & 186.1 & 114.7 & 67.7 \\
\hline 6 & 44.5 & 31.3 & 96.5 & 151.2 & 243.6 & 272.2 & 256.9 & 255.2 & 238.9 & 171.9 & 104.9 & 57.7 \\
\hline 7 & 39.4 & 29.5 & 91.2 & 141.4 & 237.7 & 241.6 & 248.4 & 243.2 & 229.1 & 167.8 & 96.2 & 36.1 \\
\hline 8 & 37.5 & 28.4 & 86.9 & 130.9 & 213.7 & 238.2 & 247.4 & 240.2 & 209.4 & 162.9 & 92.9 & 26 \\
\hline 9 & 34.9 & 22.4 & 85.9 & 121.6 & 212.5 & 236.9 & 240.2 & 236.8 & 201 & 153 & 78.4 & 25.9 \\
\hline 10 & 34 & 16.9 & 82.4 & 116.8 & 211.5 & 222.6 & 223.9 & 234.9 & 199.9 & 143.1 & 77.4 & 24.9 \\
\hline 11 & 29.8 & 16.8 & 81.4 & 112.7 & 196.1 & 207.4 & 216.3 & 227.8 & 186.5 & 133.2 & 75.8 & 17.4 \\
\hline 12 & 28.7 & 12.9 & 79.8 & 111.3 & 192.9 & 193.3 & 209.8 & 219.4 & 183.4 & 92.2 & 67.3 & 14.6 \\
\hline 13 & 27.3 & 12.3 & 77.5 & 110.3 & 192.9 & 177.2 & 189.9 & 203.5 & 183.3 & 91.7 & 54.5 & 10.5 \\
\hline 14 & 24.1 & 7.5 & 68.7 & 103.1 & 183.6 & 175 & 186.7 & 192.1 & 174 & 91.1 & 46.8 & 6.3 \\
\hline 15 & 17.8 & 5 & 67.4 & 101.4 & 173.8 & 160.3 & 181.3 & 177 & 169.9 & 79.6 & 46.5 & 3.8 \\
\hline 16 & 16.2 & 1.8 & 55.8 & 95.8 & 161.9 & 153.7 & 151.5 & 160.8 & 165.3 & 68.3 & 29.9 & 2 \\
\hline 17 & 15.8 & 17 & 46.1 & 93.2 & 137.3 & 150.4 & 149.7 & 158.7 & 148.1 & 50.8 & 29.7 & 1.4 \\
\hline 18 & 6.1 & 0.7 & 39.4 & 89.7 & 118.7 & 142.6 & 149.6 & 150.9 & 142.3 & 37 & 8.1 & 1 \\
\hline 19 & 2.1 & 0.5 & 39.3 & 71.8 & 12.2 & 128.4 & 136.1 & 132.7 & 133.4 & 32.8 & 5.9 & 0 \\
\hline 20 & 0 & 0 & 39.3 & 0 & 0 & 117.4 & 122.4 & 102.3 & 130.9 & 10.3 & 1.3 & 0 \\
\hline
\end{tabular}

(Source: ENMA; 1997-2016)

Appendix table3. Effective rainfall $(\mathrm{mm})$

\begin{tabular}{|c|c|c|}
\hline Month & Dependable rainfall & Effective rainfall \\
\hline January & 15.8 & 0 \\
\hline February & 17 & 17.66 \\
\hline March & 46.1 & 50.56 \\
\hline April & 93.2 & 85.84 \\
\hline May & 137.3 & 96.32 \\
\hline June & 150.4 & 95.76 \\
\hline July & 149.7 & 102.96 \\
\hline August & 158.7 & 94.48 \\
\hline September & 148.1 & 20.48 \\
\hline October & 50.8 & 7.82 \\
\hline November & 29.7 & 0 \\
\hline December & 1.4 & \\
\hline
\end{tabular}


Determination of Crop Water Requirement and Irrigation Water Requirement for Coffee Arabica (Coffea Arabica L.): Case Study of Somodo Watershed

The procedures are summarized as follows.

1. The probability of excedence $(\mathrm{P})$ of $80 \%$ was used to calculate the return period $(\mathrm{Tr})$ $\mathrm{P}=1 / \mathrm{Tr} ; \operatorname{Tr}=1 / \mathrm{p}=1 / 0.8=1.25$

2.The rank of rainfall with $80 \%$ probability of excedence was calculated and the corresponding monthly values were taken as dependable rainfall.

$$
\operatorname{Tr}=(\mathrm{n}+1) / \mathrm{m}
$$

Where $\mathrm{n}=$ no of events (20 years)

$$
\begin{aligned}
& \mathrm{m}=(\mathrm{n}+1) / \mathrm{Tr}, \mathrm{m}=\mathrm{rank} \quad \mathrm{m}=(\mathrm{n}+1) / \mathrm{Tr} \\
& \mathrm{m}=(20+1) / 1.25=16.8 .
\end{aligned}
$$

Therefore, the 17 th order rainfall was taken to calculate the monthly effective rainfall

Citation: Etefa Tilahun Ashine, "Determination of Crop Water Requirement and Irrigation Water Requirement for Coffee Arabica (Coffea Arabica L.): Case Study of Somodo Watershed" International Journal of Research Studies in Agricultural Sciences (IJRSAS), 2019; 5(6), pp. 1-8, http://dx.doi.org/10.20431/2454-6224.0506001

Copyright: (C) 2019 Authors. This is an open-access article distributed under the terms of the Creative Commons Attribution License, which permits unrestricted use, distribution, and reproduction in any medium, provided the original author and source are credited. 